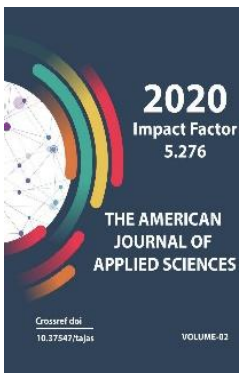

\title{
Analysis Of The Current State Of Microfinance Practice Of Commercial Banks
}

Nilufar Illhomovna Sultanova

1st Stage Doctoral Student, Tashkent State University Of Economics, Uzbekistan

Journal Website:

http://usajournalshub.c

om/index,php/tajas

Copyright: Original content from this work may be used under the terms of the creative commons attributes 4.0 licence.

\section{ABSTRACT}

This article analyzes the microfinance practices of commercial banks operating in Uzbekistan. Microcredits offered by commercial banks in the country are subject to certain conditions, such as a guarantee or work experience, the existence of age restrictions, which reduces the attractiveness of microcredits offered by commercial banks among the population.

The purpose of the study is to scientifically substantiate the above problems and make recommendations based on the analysis of microfinance activities of commercial banks.

As a result of the study, the following recommendations were made:

The development of non-bank microcredit organizations in the country will reduce the microcredit risks of commercial banks;

It is advisable to direct soft loans provided by the state to small businesses and private entrepreneurs in the country to non-bank microfinance institutions, rather than to banks with a state share.

\section{KEYWORDS}

Microfinance, commercial bank, credit, problem loans, entrepreneurship, international ratings. 


\section{INTRODUCTION}

A necessary condition for the economic development of any country is the successful functioning of the country's financial market and the effectiveness of the monetary policy pursued. In recent years, the microfinance sector has become an important component and innovative tool for the development of the country's financial and credit system. Improving the competitive environment for businesses in accordance with the Decree of the President of the Republic of Uzbekistan "On the State Program for the implementation of the Action Strategy for the five priority areas of development of the Republic of Uzbekistan in 2017-2021 in the Year of Science, Enlightenment and Digital Economy" [1] included in one of its strategic tasks. According to him, in 2020 it is planned to provide 5.5 thousand women with soft loans for small business projects in the amount of 100 billion soums, for which banks will be allocated resources from the state budget.

Laws of the Republic of Uzbekistan "On the Central Bank of the Republic of Uzbekistan", "On Banks and Banking", "On Microfinance", "On Guarantees of Freedom of Entrepreneurship" and the Decree of the President of the Republic of Uzbekistan dated August 8, 2017 No.-3182 In accordance with the Resolution "On priority measures to ensure rapid socio-economic development", the Regulation "On the procedure for allocating microcredits by commercial banks for employment" established the procedure for allocating microcredits by commercial banks [2].

Microloans are issued by banks or non-bank microcredit organizations on the terms of repayment, repayment, security, maturity and intended use. Microcredits are issued primarily on preferential terms to create decent living conditions for the population in the regions, to provide employment to the population who want to engage in certain types of work through entrepreneurship.

In accordance with the legal framework of the Republic of Uzbekistan, microcredits:

Repayment of previously received loans or any other debts;

Production of alcohol and tobacco products;

Formation of working capital of trade intermediaries and public catering organizations;

financing the construction of trade and catering facilities, organization of gambling and other risk-based games and the purchase of equipment for them;

Purchase of personal property not used for production purposes;

Payment of administrative expenses, including the provision of service vehicles;

Furniture, purchase of a mobile phone, as well as communication services may not be provided for payment purposes.

The functions of the state as a regulator of the microfinance sector of the economy are, first of all, the development and organization of the regulatory framework for the implementation of microfinance activities. Approved by Presidential Decree No.-4400 of 23.07.2019 "On measures to increase the popularity of microfinance services" [3]. According to them, the following has changed:

Previously, the maximum amount of a microcredit was 100 minimum wages. Now it is limited to 50 million soums. The maximum amount of microcredits is 300 million soums (instead of the minimum wage of 1,000), and 
microleasing - 600 million soums (instead of the minimum wage of 2,000) [4].

It should be noted that microcredits offered by commercial banks in the country are subject to certain conditions, such as a guarantee or work experience, the presence of age restrictions, which reduces the attractiveness of microcredits offered by commercial banks among the population.

While microcredits are the main goal in the economy to support the activities of small businesses and private entrepreneurship, we can also see that the high percentage of microcredits offered by commercial banks in the country does not meet the economic purpose of microcredits.

The purpose of the study is to scientifically substantiate the above problems and make recommendations based on the analysis of microfinance activities of commercial banks.

\section{LEVEL OF STUDY OF THE TOPIC}

Theoretical, methodological and scientific bases of microfinance have been widely studied by Uzbek scientists for the last 10 years.

In particular, Mamatov B.S. His research shows that "in developed countries, small business and private entrepreneurship form the basis of the economy and have a direct impact on its successful development. In particular, more than $50 \%$ of the economically active population is involved in small business and private entrepreneurship. This figure is $70 \%$ in Japan, $80 \%$ in China and $50 \%$ in the United States. The share of small business and private entrepreneurship in the gross domestic product (GDP) is $52 \%$ in the United States and $67 \%$ in Japan. In developed countries, the number of small businesses accounts for $70-90 \%$ of total enterprises, and $70-80 \%$ of the total employed population. From this point of view, ensuring the development of small business is a priority" [5].

Tursunov R.T. Effective implementation of measures to develop the mechanism of lending to small business and private entrepreneurship in research: to reduce the number of unemployed and provide employment through the creation of new jobs; to create a modern system of microfinance that fully covers the population in need of microfinance services in all regions of the country; formation of a broad stratum of middle-class owners in the future through the broad involvement of the poor but economically active population and youth in entrepreneurial activities; increase the volume of microfinance of small businesses and private entrepreneurship by commercial banks and non-bank credit organizations; sustainable development of the microfinance sector and its infrastructure; increase the contribution of small business and private entrepreneurship in the formation of state budget revenues and, ultimately, the strengthening of macroeconomic and financial stability and sustainable economic growth [6].

Mamuta M.V., Sorokina O.S. In his research, he noted that microfinance is one of the important pillars of increasing social protection in the economy and its widespread use in developing countries, as well as the need to develop mechanisms for microfinance, debt repayment, risk assessment and prevention to establish a microfinance system in the country [7].

\section{RESEARCH METHODOLOGY}

Statistical methods were used effectively throughout the study.

In particular, the grouping method was used in the study of commercial banks' ratings on international ratings, and the method of comparative analysis was used in the study of the liabilities of microcredit organizations for 2017-2020. 


\section{ANALYSIS AND RESULTS}

Despite the fact that 2020 is one of the most responsible financial periods for the country's economy, in the first 6 months of 2020 the share of financial services in total market services was $24.4 \%$, an increase of $133.9 \%$ compared to the same period last year. and the growing demand for microcredit services among the population. Probably, this is due to the fact that more than 30 commercial banks in the country have "stable" ratings from international rating agencies such as Moody's, Stanadart and Poors, and Fitch Ratings (Table 1).

Table 1. Ratings of commercial banks by international rating agencies [8]

\begin{tabular}{|c|c|c|c|}
\hline № & Name of banks & $\begin{array}{l}\text { Name of the rating } \\
\text { agency }\end{array}$ & $\begin{array}{l}\text { Rating } \\
\text { price }\end{array}$ \\
\hline 1 & NBU, Asakabank, Ipotekabank & $\begin{array}{l}\text { Moody's, Standard \& } \\
\text { Poor's }\end{array}$ & "Stable" \\
\hline 2 & Uzsanoatqurilishbank & $\begin{array}{l}\text { Standard \& Poor's, } \\
\text { Fitch Ratings }\end{array}$ & "Stable" \\
\hline 3 & $\begin{array}{l}\text { Qishloq Qurilish Bank, Aloqabank, Asia } \\
\text { Alliance Bank, Hamkorbank, UT Bank, } \\
\text { Savdogarbank, Invest Finans Bank }\end{array}$ & Moody's & "Stable" \\
\hline 4 & Agrobank, Silk Road Bank & Fitch Ratings, Moody's & "Stable" \\
\hline 5 & Microcreditbank, Trustbank, Universalbank & Fitch Ratings & "Stable" \\
\hline 6 & $\begin{array}{l}\text { Xalq Bank, Turonbank, Kapital Bank, KDB } \\
\text { Bank Uzbekistan, Davrbank, Hay-Tek Bank, } \\
\text { Orient Finance Bank, Turkistonbank, } \\
\text { Ravnaqbank }\end{array}$ & «Standard and Poor's» & "Stable" \\
\hline 7 & Iron Soderot bank & «Expert RA» & "Stable" \\
\hline
\end{tabular}

In the 21st century, it is difficult to imagine the activities of modern commercial banks without credit and microcredit services. In
Uzbekistan, almost all commercial banks are engaged in microcrediting (Table 2 ). 
Table 2. Bank lenders in Uzbekistan [9]

\begin{tabular}{|c|c|c|c|c|}
\hline Bank name & Credit & Percent & Duration & Terms of service \\
\hline Agrobank & $\begin{array}{l}\text { Up to } 20 \\
\text { million soums }\end{array}$ & $34 \%, 36 \%$ & $\begin{array}{l}1 \text { year, } 2 \\
\text { years }\end{array}$ & \\
\hline Asia Alliance Bank & $\begin{array}{l}\text { Up to } 10 \\
\text { million soums }\end{array}$ & $30 \%$ & Up to 1 year & $18-60$ years old \\
\hline InFinBank & $\begin{array}{l}\text { Up to } 20 \\
\text { million soums }\end{array}$ & $32 \%$ & $\begin{array}{l}\text { Up to } 2 \\
\text { years }\end{array}$ & $\begin{array}{l}\text { At least } 6 \text { months of } \\
\text { work experience }\end{array}$ \\
\hline "Silk Road Bank" & $\begin{array}{l}\text { Up to } 20 \\
\text { million soums }\end{array}$ & $\begin{array}{l}32 \% \text { (cash), } \\
30 \% \text { (bank } \\
\text { card) }\end{array}$ & Up to 1 year & On a warranty basis \\
\hline Qishloq Qurilish Bank & $\begin{array}{l}\text { Up to } 20 \\
\text { million soums }\end{array}$ & $\begin{array}{l}3 \% \text { per } \\
\text { month }\end{array}$ & Up to 1 year & 1 month discount \\
\hline Orient Finans Bank & $\begin{array}{l}\text { Up to } 4 \text { million } \\
\text { soums }\end{array}$ & $30 \%, 32 \%$ & $\begin{array}{l}6 \text { months, } \\
\text { up to } 1 \text { year }\end{array}$ & $\begin{array}{l}\text { When taking a bank } \\
\text { card, the rate is } \\
\text { reduced to } 2 \%\end{array}$ \\
\hline Uzsanoatqurilishbank & $\begin{array}{l}\text { Up to } 20 \\
\text { million soums }\end{array}$ & $\begin{array}{l}\text { Not less } \\
\text { than } 32 \%\end{array}$ & Up to 1 year & $\begin{array}{l}\text { It is possible to } \\
\text { formalize on a } \\
\text { special application, } \\
\text { but the rate can be } \\
\text { increased up to } 48 \\
\text { percent. }\end{array}$ \\
\hline
\end{tabular}

Microloans can be issued for a period of $1-3$ years at a rate of $3 \%$ per month up to 100 times the minimum wage.

Uzbekistan also has a system of microleasing, which is provided in the national currency for a period of $13-36$ months at a rate of up to 2,000 times the minimum wage from $30 \%$ per month.

Consumer loans are one of the types of microcredits in Uzbekistan, which are made by transferring funds by a bank or other credit institution to the bank account of the enterprise producing or selling consumer goods (services) produced in the Republic of Uzbekistan. It is provided in the amount of up to 200 times the minimum wage.

The development of a microfinance system is beneficial not only for small businesses and private entrepreneurs, but also for organizations engaged in microfinance. In the microfinance system, the rapid turnover of money and the long-term non-issuance of loans play an important role in ensuring that the solvency of the organization does not decline. 
The microfinance system in the country is improving. In order to create favorable conditions for further development of microfinance, on March 17, 2020, the President signed the Law "On Amendments to the Law of the Republic of Uzbekistan" On Microfinance ".

Table 3. Liabilities and assets of microcredit organizations (billion soums) [10]

\begin{tabular}{|c|c|c|c|c|c|}
\hline Key indicators & 01.01 .2017 & 01.01 .2018 & 01.01 .2019 & 01.01 .2020 & $\begin{array}{l}\text { In } 2020 \\
\text { compared to } \\
2017 \text { (many } \\
\text { times more) }\end{array}$ \\
\hline \multicolumn{6}{|c|}{ Liabilities } \\
\hline Loans and leases & 19,8 & 31,0 & 103,6 & 252,5 & 12,75 \\
\hline $\begin{array}{l}\text { Accrued interest } \\
\text { payable }\end{array}$ & 0,3 & 0,4 & 1,3 & 7,7 & 25,6 \\
\hline $\begin{array}{l}\text { Accrued taxes } \\
\text { payable }\end{array}$ & 0,6 & 0,9 & 2,2 & 1,0 & 1,6 \\
\hline Other obligations & 3,9 & 1,6 & 8,2 & 10,5 & 2,7 \\
\hline \multicolumn{6}{|c|}{ Assets } \\
\hline Charter capital & 44,4 & 65,9 & 169,5 & 277,6 & 6,25 \\
\hline Reserve capital & 6,2 & 8,2 & 10,4 & 15,5 & 2,5 \\
\hline
\end{tabular}

Compared to 2017, in 2020 we can see that the number of loans and leases received by microcredit organizations increased by 12.75 times, accrued interest by 25.6 times, accrued taxes by 1.6 times and other liabilities by 2.7 times.
In particular, we can see that the assets of microcredit organizations have also increased. The authorized capital increased by 6.25 times in 2020 compared to 2017, and the reserve capital increased by 2.5 times. 
Table 4. Problem loans of commercial banks(NPL) as of August 1, 2020, billion soums. [11]

\begin{tabular}{|c|l|c|c|c|}
\hline № & \multicolumn{1}{|c|}{ Bank name } & Loans & $\begin{array}{l}\text { Problem loans } \\
\text { (NPL) }\end{array}$ & $\begin{array}{l}\text { The share of problem loans } \\
\text { in total loans }\end{array}$ \\
\hline \multicolumn{1}{|c|}{ Total } & $\mathbf{2 4 9 7 5 6}$ & $\mathbf{5 8 8 7}$ & $\mathbf{2 , 4 \%}$ \\
\hline \multicolumn{2}{|c|}{ Banks with state share } & $\mathbf{2 2 1 ~ 2 8 4}$ & $\mathbf{5 3 0 6}$ & $\mathbf{2 , 4 \%}$ \\
\hline 1 & NBU & 61653 & 1655 & $2,7 \%$ \\
\hline 2 & Uzsanoatqurilishbank & 37142 & 582 & $1,6 \%$ \\
\hline 3 & Asaka bank & 31629 & 1263 & $4,0 \%$ \\
\hline 4 & Ipoteka bank & 21442 & 605 & $2,8 \%$ \\
\hline 5 & Aloqa bank & 5462 & 125 & $2,3 \%$ \\
\hline 6 & Asia Alliance Bank & 1719 & 45 & $2,6 \%$ \\
\hline 7 & Capital bank & 92 & 1 & $1,3 \%$ \\
\hline 8 & Uzagroexportbank & 87 & 7 & $8,6 \%$ \\
\hline & Other banks & $\mathbf{2 8 4 7 2}$ & $\mathbf{5 8 1}$ & $\mathbf{2 , 0 \%}$ \\
\hline 9 & Hamkorbank & 6846 & 292 & $4,3 \%$ \\
\hline 10 & Silk Road Bank & 4417 & 197 & $2,0 \%$ \\
\hline 11 & Trust bank & 39 & & \\
\hline
\end{tabular}

At the beginning of the year, the total volume of problem loans of banks in the country amounted to 3.2 trillion soums, of which unsatisfactory - $43 \%$, doubtful - $19 \%$ and bad $38 \%$.

The share of problem loans in the total volume of loans is an indicator of the quality of the loan portfolio, the growth of which is a key factor that will lead to serious losses and liquidity problems in the future. On January 1 , the figure was 1.5 percent.

Decrease in the quality of assets in banks - the ratio of unemployed loans to total capital, which indicates a possible decrease in bank capital, decreased by $1.6 \%$ in 2019 and amounted to $2.7 \%$ as of January 1 .

The 2020 pandemic has affected the banking system as well as other sectors of the country's economy. In the wake of the pandemic, the share of problem loans has increased as a result of declining incomes and financial losses of businesses. As of August 1, 2020, the share of non-performing loans in total loans was $2.4 \%$ (Table 4). Among the state-owned banks, the share of problem loans in Uzagroexportbank was $8.6 \%$. The 
main reason for this may be loans provided by the state on favorable terms. Among other banks, the share of problem loans in the Silk Road Bank in total loans was $4.5 \%$. As of August 1, 2020, the total volume of problem loans in the country amounted to 5,887 billion soums.

\section{CONCLUSIONS AND SUGGESTIONS}

As a result of the above research, the following conclusions were drawn:

- The growing liabilities of the country's microfinance institutions reduce their liquidity. For this reason, in order to prevent problem loans, most commercial banks set requirements for age and property and income of individuals in the process of providing loans and microloans;

- The development of the microfinance system is beneficial not only for small businesses and private entrepreneurs, but also for organizations engaged in microfinance. In the microfinance system, the rapid turnover of money and the long-term non-issuance of loans play an important role in ensuring that the solvency of the organization does not decline. However, the relatively slow circulation of money supply in the country during the pandemic and the freezing of interest rates for some time also affected the liabilities of commercial banks.

Based on the above, the following is suggested:

- Due to the large number of services provided by commercial banks, it is advisable to provide microfinance services by non-bank microfinance organizations. Although the increase in interest rates as a result of the implementation of microfinance services by non-bank microcredit organizations leads to a decrease in other requirements for obtaining credit;

- It is expedient to direct soft loans provided by the state to small businesses and private entrepreneurs in the country to non-bank microfinance institutions, rather than to banks with a state share. The implementation of such measures will be an important basis for the development of non-bank financial institutions, as well as increase their attractiveness.

\section{REFERENCES}

1. Decree of the President of the Republic of Uzbekistan "On the state program for the implementation of the strategy of actions in five priority areas of development of the Republic of Uzbekistan in 2017-2021" in the "Year of Science, Enlightenment and Digital Economy" No-5953. 02.03.2020. https://lex.uz/docs/4751561?ONDATE=03.0 3.2020

2. Resolution of the Board of the Central Bank of the Republic of Uzbekistan "On approval of the Regulation on the procedure for allocating microcredits by commercial banks to ensure employment." [Registered by the Ministry of Justice of the Republic of Uzbekistan on February 22, 2018, registration number 2975] https://uzpsb.uz/generalinformation/innformation-disclosure/a-oliindustrial-to-provide-tizhorat-banksmicrocredits -azhratish-order-t-risi /

3. Decree of the President of the Republic of Uzbekistan dated 23.07.2019 No PP4400 "On measures to increase the popularity of microfinance services." https://lex.uz/docs/4435438

4. https://uz.sputniknews.ru/economy/20190 725/12084781/Uzbekistan-sistemamikrokreditovaniya.html 
5. Mamatov B.S. Issues of microfinance of small business and private entrepreneurship. International electronic journal "Finance and Accounting". №1, February, 2017. www.interfinance.uz

6. Tursunov R.T. The role of lending in increasing the share of small business and private entrepreneurship in the country's economy. Scientific electronic journal "Economy and Innovative Technologies". № November 2, 2011. http://iqtisodiyot.tsue.uz/sites/default/file s/maqolalar/43_P.T.Tursunov.pdf

7. Mamuta, Mikhail \& Sorokina, Olga. (2015). Introduction to microfinance. Global Markets and Financial Engineering. 2. 143. 10.18334 / grfi.2.2.539.

8. Data of the Central Bank of the Republic of Uzbekistan. http://www.cbu.uz/oz/

9. Review: on certain conditions you can get a microloan in a bank in Uzbekistan. https://www.spot.uz/ru/2019/04/08/microl oan/

10. Data of the Central Bank of the Republic of Uzbekistan.

http://www.cbu.uz/oz/creditorganizations/

11. Data of the Central Bank of the Republic of Uzbekistan.

http://www.cbu.uz/oz/creditorganizations/ 